\title{
The Scale of Excessive Use of Social NETWORKING SITES - THE PSYCHOMETRIC CHARACTERISTICS AND VALIDITY OF A PROPOSED TOOL
}

\section{SKala OCEny NADMIERNEgo KORZYSTANIA \\ Z SIECI SPOKECZNOŚCIOWYCH - \\ CHARAKTERYSTYKA PSYCHOMETRYCZNA \\ I WALIDACJA PROPONOWANEGO NARZĘDZIA}

\author{
Martyna Kotyśko $^{1}$ (ID), Maciej Michalak² (D) \\ ${ }^{1}$ Department of Clinical Psychology, Development and Education, Institute of Pedagogical Science, Faculty of Social Sciences, \\ University of Warmia and Mazury in Olsztyn, Olsztyn, Poland \\ ${ }^{2}$ Faculty of Psychology, Kazimierz Wielki University, Bydgoszcz, Poland \\ ${ }^{1}$ Katedra Psychologii Klinicznej, Rozwoju i Edukacji, Instytut Nauk Pedagogicznych, Wydział Nauk Społecznych, Uniwersytet \\ Warmińsko-Mazurski w Olsztynie, Olsztyn, Polska \\ ${ }^{2}$ Wydział Psychologii, Uniwersytet Kazimierza Wielkiego w Bydgoszczy, Polska
}

Alcohol Drug Addict 2020; 33 (3): 239-252 DOI: https://doi.org/10.5114/ain.2020.101800

\begin{abstract}
Introduction: The paper describes the process of developing a tool to measure social networking site addiction among adolescents, that is the Scale of Excessive Use of Social Networking Sites (SEUS).

Material and methods: Three studies (Study 1, $N=587$; Study 2, $N=351$; Study 3, $N=1054$ ) were performed to establish psychometric properties, construct and criterion validity of SEUS
\end{abstract}

\section{Streszczenie}

Wprowadzenie: Artykuł przedstawia narzędzie do pomiaru uzależnienia od portali społecznościowych wśród adolescentów - Skalę Oceny Nadmiernego Korzystania z Sieci Społecznościowych (SONKSS).

Materiał i metody: Właściwości psychometryczne oraz trafność teoretyczna i kryterialna SONKSS były szacowane $\mathrm{w}$ trzech badaniach $\mathrm{z}$ udziałem polskich uczniów szkół średnich (Badanie 1,

Correspondence to/Adres do korespondencji: Martyna Kotyśko, Katedra Psychologii Klinicznej, Rozwoju i Edukacji, Wydział Nauk Społecznych, Uniwersytet Warmińsko-Mazurski, ul. Prawocheńskiego 13/302B, 10-447 Olsztyn, Polska, phone: +48 895246229 , fax 89523 5057, e-mail: martyna.kotysko@uwm.edu.pl

Authors' contribution/Wkład pracy autorów: Study design/Koncepcja badania: M. Kotyśko, M. Michalak; Data collection/Zebranie danych: M. Kotyśko, M. Michalak; Statistical analysis/Analiza statystyczna: M. Kotyśko; Data interpretation/Interpretacja danych: M. Kotyśko; Acceptance of final manuscript version/Akceptacja ostatecznej wersji pracy: M. Kotyśko, M. Michalak; Literature search/ Przygotowanie literatury: M. Kotyśko; Funds collection/Pozyskanie środków (finansowania): M. Michalak

No ghostwriting and guest authorship declared./Nie występują zjawiska ghostwriting i guest authorship.

Submitted/Otrzymano: 21.10.2019 • Accepted/Przyjęto do druku: 29.04.2020

(C) 2020 Institute of Psychiatry and Neurology. Production and hosting by Termedia sp. z o.o.

This is an open access article under the CC BY-NC-ND license (http://creativecommons.org/licenses/by-nc-nd/4.0/) 
among Polish high school students. Two different versions of SEUS were developed (48- and 30-item). Their results were correlated with the Bergen Facebook Addiction Scale (BFAS) and standardised questionnaires for measuring psychological variables.

Results: SEUS construct validity was checked with Exploratory Factor Analysis (EFA) and Confirmatory Factor Analysis (CFA) procedures. The long 48 -item version was reduced to 14 items on which SEUS-14 is based. The final one-factor solution explained $57.7 \%$ of variance. The reliability measured with Cronbach's $\alpha$ is very good. SEUS-14 correlates with BFAS and psychological measures of personality traits, narcissism, self-esteem and Behavioural Activation System, which confirms the scale criterion validity.

Discussion: The presented study findings are consistent with the results of other research on Facebook or internet addiction. Regarding the construct validity, one-factor solution turned out to be the best while correlation analysis confirmed SEUS criterion validity.

Conclusions: SEUS-14 has demonstrated good psychometric properties in a national sample of Polish adolescents. The measure, treated as a screening tool, can be used for scientific purpose though further studies on the broader use of the scale are necessary.

Keywords: Validity, Behavioural addictions, Adolescents, Social networking sites.
$N=587$; Badanie 2, $N=351 ;$ Badanie $3, N=1054)$. Opracowano dwie wersje SONKSS (48- i 30-itemową), a ich wyniki zostały skorelowane z Bergeńską Skalą Uzależnienia od Facebooka (BFAS) i wystandaryzowanymi kwestionariuszami do pomiaru zmiennych psychologicznych.

Wyniki: Trafność teoretyczna SONKSS była sprawdzana $\mathrm{w}$ procedurach EFA i CFA. Długa wersja SONKSS (48-itemowa) została zredukowana do 14 itemów, które zostały uwzględnione w skróconej wersji proponowanego narzędzia (SONKSS-14). Końcowe jednoczynnikowe rozwiązanie wyjaśnia 57,7\% wariancji. Rzetelność mierzona współczynnikiem $\alpha$ Cronbacha była bardzo wysoka. SONKSS-14 korelował ze skalą BFAS, psychologicznymi miarami cech osobowości, narcyzmu, samooceny i Behawioralnym Systemem Aktywacyjnym, co potwierdza trafność kryterialną skali.

Omówienie: Przedstawione doniesienia są zgodne z wynikami innych badań nad uzależnieniem od Facebooka lub internetu. Rozwiązanie jednoczynnikowe przedstawiało najwyższy poziom trafności teoretycznej, a analiza korelacji potwierdziła trafność kryterialną SONKSS.

Wnioski: Badania przeprowadzone na próbie polskich adolescentów pokazały, że skala SONKSS-14 ma dobre właściwości psychometryczne. Skala może być stosowana jako narzędzie przesiewowe do celów naukowych, jednak dalsze badania są potrzebne, by określić jej szerzej zakrojone zastosowanie.

Słowa kluczowe: trafność, uzależnienia behawioralne, adolescenci, sieci społecznościowe.

\section{- INTRODUCTION}

Social networking sites (SNS) enjoy enormous global popularity with more than one and a half billion people using Facebook on a daily basis [1]. There are many other sites that enable users to communicate, share information and have fun in the virtual world. The ease of access to social networks, the rapid increase in the number of users, and the high participation of community members in various SNS have spurred research aiming to determine whether SNS, like the internet itself, leads to addiction, dependence or problematic use. In an era of rapid technological advancement, when SNS can be accessed not only through PCs or laptops, but also through smartphones and tablets, the criteria for distinguishing "normal" and addictive use of social media are very difficult to define. The key question that remains is whether people can become addicted to or use SNS excessively.

Mark Griffiths [2] proposed the following components of addiction: salience, mood modification, tolerance, withdrawal symptoms, conflict and relapse. These components are generally used to determine the initial criteria for addictive behaviour like SNS addiction [3, 4]. Several research tools have been developed to measure SNS addiction or problematic use (especially Facebook use). The best known is the Bergen Facebook Ad- 
diction Scale (BFAS) developed in Norway [3]. The BFAS has been criticised by Griffiths [5], who argued that the tool is applicable to only one SNS and does not support diagnoses of addiction to a specific Facebook activity. A modified version of the above tool, the Bergen Social Media Addiction Scale (BSMAS), has been developed [6]. However, researchers also rely on other screening tools to analyse SNS addiction. One is the Facebook Intrusion Questionnaire (FIQ) [7], which has high substantive value and was developed in 2011, before the BFAS. The FIQ consists of eight items which are based on, among others, Brown's behavioural addiction components [7]. The Internet Addiction Test proposed by Kimberley Young [8] is often modified for research purposes to support the acquisition of information related to Facebook addiction (FA) $[9,10]$. The Social Media Disorder Scale was created in response to the inclusion of potential Internet Gaming Disorder (IGD) criteria in the DSM-5 [11]. The scale consists of nine items that each correspond to specific IGD criteria adapted for evaluation of social media disorder (SMD).

Studies into social media addiction produce highly diverse results due to the absence of unambiguous criteria for diagnosing Facebook addiction. A study conducted in Bangladesh demonstrated that around $40 \%$ of the participants were addicted to Facebook [12]. In a Polish study by Błachnio and Przepiórka [13], more than 29\% of the participants $(N=123)$ were identified as Facebook addicts based on the results of cluster analysis. In another cluster analysis study, Błachnio, Przepiórka and Pantic [14] also classified 123 participants as addicted to Facebook (the majority of the respondents were women). A study of Peruvian students revealed $8.6 \%$ respondents had Facebook addiction [15]. In contrast, only one percent of the participants were classified as "Facebook addicts" in a Taiwanese study [16] where women were also the majority. The varied outcomes regarding the prevalence of Facebook addiction (FA) have been addressed by Andreassen [17] among others in a review of studies focusing on SNS addiction. According to van den Eijnden et al. [11] the fragmentation of research in the field of social media can be attributed to rapid changes in the SNS as well as the adoption of various criteria for measuring specific forms of social media addiction.
Development of the Scale of Excessive Use of Social Networking Sites (SEUS)

As indicated in the previous paragraph, in 2012 a few tools (based on different addiction criteria) were available for measuring Facebook addiction, including the popular BFAS. It should be noted, however, that this scale was developed based on the Griffiths addiction components, and at that time the authors of the scale informed about the limitations of the tool. The basic one was that the sample on which studies were carried out consisted of students only. It was also pointed out that the cut-off criteria for categorising the subjects were not estimated [3]. In the next year, 2013, we decided to develop a Polish tool for diagnosing potentially excessive use of the SNS, referred to as the Scale of Excessive Use of Social Networking Sites (SEUS). The decision to develop our own tool was dictated by several reasons. First, the existing tools were geared towards measuring addiction covering only the selected SNS, mainly Facebook, and we wanted to capture the problem in relation to the various SNS used. The second reason was the group of respondents, which were adolescents who may be more prone to SNS addiction. At that time no research was being conducted in this group and there was no information on how the functioning tools work among younger participants. Thirdly, we wanted to build a tool on existing criteria and test how they reveal themselves among adolescents, who perhaps should not be treated in the same way as adults in terms of time frames and cut-off points for addiction/problematic use.

In connection with the above assumptions, the ICD-10 criteria for dependence syndrome [18], the DSM-IV criteria for pathological gambling [19] and Young's Internet Addiction criteria [20] were adopted at the theoretical and clinical level. It is worth noting that Internet Gaming Disorder (IGD) criteria (presently most often used to analyse behavioural addictions) were unknown at the time. Therefore we decided to use other determinants to develop our own scale. Seven factors that are associated with potentially excessive use of SNS were identified like preoccupation, loss of control, withdrawal, tolerance, neglect, use of SNS despite negative consequences, and mood modification/escapism.

The research team has developed a pool of 48 questions concerning excessive use of the SNS as 
well as instructions for the respondents. The responses were rated on the Likert scale, where strongly disagree was 1 and 5 denoted strongly agree. Unlike other measures for assessing excessive use of SNS, the developed questionnaire did not contain a reference period for reporting online activity. In studies conducted on adults, activities such as pathological gambling were reported within a time frame of one year, which could be too long for young people due to this age group's time perspective.

\section{Research purpose and hypothesis}

The main aim of the research was to create a tool for measuring problematic use of SNS that would be characterised by good psychometric parameters and could be adapted to adolescents at highest risk of social media addiction.

The proposed tool was validated and this process included several actions. The first one was validation of the factor structure of the scale (construct validity). A seven-factor scale was designed and the extent to which the collected research data reflected the adopted concept underwent verification. Second, internal consistency (reliability verification) was analysed. The third action was related to criterion validity and its two types: concurrent and convergent. Concurrent validity was assessed with the use of the BFAS [3]. The BFAS features different criteria than the SEUS, but the underlying concept is very similar. We expected the results of the BFAS and the SEUS to be highly correlated. The evaluation of convergent validity also involved an analysis of the correlations between the SEUS and psychological variables that were significantly related to the problematic use or addiction to the internet and SNS in the existing research.

The Behavioral Inhibition System (BIS) and the Behavioral Activation System (BAS) are a part of Gray's Reinforcement Sensitivity Theory (RST) and are related to sensitivity to punishment (BIS) and reward (BAS) [21]. The two personality traits that are most often associated with these systems are anxiety (BIS) and impulsiveness (BAS) [22]. We assumed that the SEUS would correlate positively with the results of the BAS scale due to the associations with impulsiveness which were demonstrated by previous studies on internet addiction [23-25]. Studies into the BIS produced ambiguous results. An analysis of the literature on internet addiction revealed that this variable was positively correlated with addiction in some studies [23, 25], but not in others [24]. Therefore, we assumed that this variable should positively correlate with the results of the SEUS scale.

Many studies have demonstrated a link between personality traits, internet addiction [26, 27] and problematic usage of SNS [3, 4, 13, 28]. We expected the SEUS to correlate positively with Emotionality and Extraversion and negatively with Honesty/Humility, Agreeableness, Openness and Conscientiousness dimensions in the HEXACO Personality Inventory. Based on the published findings $[6,11,28]$, we also predicted that self-esteem, regarded as a personality trait, would correlate negatively with the SEUS.

Narcissism, which is an important variable in the current research on Facebook Addiction (FA) $[6,29]$, was considered as a form of behaviour rather than a disorder [30, 31]. However, since narcissism is significantly related to SNS addiction $[6,28,29]$, similar relationships could be expected in our study.

Parameters related to the use of SNS, i.e. daily time spent on SNS, frequency of posting and changing profile photos, were also included in anticipation that these factors would be positively correlated with problematic SNS usage.

Three separate studies were conducted to estimate the psychometric properties of the 48 -item and 30 -item versions of the SEUS. The abridged version of the scale (SEUS-14) was also presented.

\section{- MATERIAL AND METHODS}

\section{Participants and procedure}

Three surveys (two face-to-face and one online) were conducted among high school students from different Polish voivodships between April 2013 and May 2014 (Table I).

The face-to-face surveys were traditional paper-pencil questionnaires. In the online survey, each student was provided with a login and a password to the research website containing in the questionnaires. Each participant received only one login to prevent the same person from completing the questionnaire multiple times. All surveys were voluntary and the students were informed that they could withdraw at any time. The questionnaires were completed anonymously during class with the school principal's prior consent. Students who did not have a social media 
The Scale of Excessive Use of Social Networking Sites...

Skala Oceny Nadmiernego Korzystania z Sieci Społecznościowych...

Table I. Sample characteristics, information about measures applied in each study and the short study purpose

\begin{tabular}{|c|c|c|c|}
\hline & $\begin{array}{l}\text { Study } 1 \text { (offline) } \\
\qquad N=587\end{array}$ & $\begin{array}{l}\text { Study } 2 \text { (offline) } \\
\qquad N=351\end{array}$ & $\begin{array}{l}\text { Study } 3 \text { (online) } \\
\quad N=1054\end{array}$ \\
\hline Number of Voivodships & 8 & 4 & 16 \\
\hline Boys, $n(\%)$ & $295(50.26)$ & $178(50.71)$ & $599(56.83)$ \\
\hline Girls, $n(\%)$ & $292(49.74)$ & $173(49.29)$ & $455(43.17)$ \\
\hline Age, $M \pm S D$ & $17.38 \pm 0.79$ & $16.8 \pm 0.84$ & $17.37 \pm 0.92$ \\
\hline BVS, $n(\%)$ & $103(17.55)$ & $93(26.49)$ & $236(22.39)$ \\
\hline TSS, $n(\%)$ & $216(36.80)$ & $118(33.62)$ & $423(40.13)$ \\
\hline GSS, $n(\%)$ & $268(45.65)$ & $140(36.89)$ & $395(37.48)$ \\
\hline Measures used & $\begin{array}{l}\text { SEUS-48, SUQ and } \\
\text { BFAS }\end{array}$ & SEUS-48 and SUQ & $\begin{array}{l}\text { SUQ, HEXACO-PI-R, BIS/BAS Scales, NPI, SES, } \\
\text { SEUS-30 }\end{array}$ \\
\hline Study purpose & EFA & CFA, PCA & $\begin{array}{c}\text { CFA, PCA, correlations between SEUS and other } \\
\text { variables }\end{array}$ \\
\hline
\end{tabular}

BVS - basic vocational school, TSS - technical secondary school, GSS - general secondary school, SEUS - the Scale of Excessive Use of Social Networking Sites, SUQ - the Social Networking Sites Usage Questionnaire, BFAS - The Bergen Facebook Addiction Scale, HEXACO-PI-R - The HEXACO Personality Inventory - Revised, NPI - the Narcissistic Personality Inventory, SES - the Rosenberg Self-Esteem Scale, EFA - Exploratory Factor Analysis, CFA - Confirmatory Factor Analysis, PCA - Principal Component Analysis, M - mean, SD - standard deviation

account, subjects who failed to complete the questionnaire or gave biased answers were excluded from the study.

\section{Measures}

Two versions of the SEUS were developed, one with 48 items (offline studies) and a shorter version with 30 (online study). The scale was theoretically divided into seven factors: preoccupation (8 items), loss of control (3 items), withdrawal (6 items), tolerance (3 items), neglect (4 items), use of SNS despite negative consequences (17 items), mood modification/escapism (7 items). The answers were rated on a 5-point Likert scale, where strongly disagree was 1 and 5 denoted strongly agree. The values of Cronbach's $\alpha$ were presented in the Results section.

The information on SNS usage was gathered with the 23-item Social Networking Sites Usage Questionnaire (SUQ). Most answers were rated on the Likert scale, and the respondents were asked to indicate how long they were SNS users, how much time they spent on SNS each day and how often they changed their SNS profile photo. They were also asked to indicate the SNS where they had an account/profile.

The Bergen Facebook Addiction Scale (BFAS) is an 18-item scale for measuring the severity of Facebook addiction. Only six items have a diagnostic function [3]. We received permission from the authors of the BFAS to develop the Polish language version of the scale. Minor modifications were introduced relative to the original scale. Our research targeted all SNS users therefore, the term "Facebook" was replaced by "social networking site". The time frame for reporting online activity was shortened from one year to six months because the respondents were adolescents. The answers were rated on a 5-point Likert scale where very rarely was 1 and 5 denoted very often. Cronbach's $\alpha$ for the six-item scale was 0.83 .

The Polish version (Szarota and Izdebski, unpublished research sheet) of the 60-item HEXACO Personality Inventory - Revised, developed by Ashton and Lee [32] was used to measure six personality traits Honesty-Humility, Emotionality, Extraversion, Agreeableness, Conscientiousness and Openness to Experience. The answers were rated on a 5-point Likert scale, where strongly disagree was 1 and 5 denoted strongly agree. Cronbach's $\alpha$ was highest for Honesty-Humility (0.74) and lowest for Agreeableness (0.57).

The Reinforcement Sensitivity Theory developed by J. Gray [33] constitutes the theoretical basis for the BIS/BAS scales. According to the above theory, two basic systems responsible for human behaviour are the Behavioral Inhibitory System (BIS) and the Behavioral Activation System (BAS). The BIS/BAS scales were originally adapted to Polish conditions by Müller and Wytykowska [34]; however, the version developed by Bernatowicz [35] was used because it was directly available. This version of the BIS/BAS scales consists 
of 15 items that make up the BIS (6 items) and BAS (9 items) scales. The answers are rated on a 4-point Likert scale where 1 was strongly disagree and 4 denoted strongly agree. Cronbach's $\alpha$ was 0.75 for BIS and 0.82 for BAS.

The Narcissistic Personality Inventory (NPI) by Raskin and Hall [36] measures narcissism as a personality trait, although its assumptions are based on the criteria for the narcissistic personality disorder. The Polish version of the inventory, NARPI-34, was developed by Bazińska and Drat-Ruszczak [37], and includes 34 questions that form four scales: demand for admiration, vanity, self-sufficiency and leadership. Answers are rated on a 5-point Likert scale, where 1 is it's not me and 5 denotes it's me. Cronbach's $\alpha$ ranged from 0.74 to 0.89 in the subscales and was determined at 0.94 for the full scale.

Self-esteem was measured with the Rosenberg Self-Esteem Scale (SES). The scale is based on M. Rosenberg's concept of self-esteem, which is regarded as a permanent construct with characteristics resembling a trait. Self-esteem is associated with cognitive self-assessment [38]. The Polish version of the scale was developed by Łaguna, Lachowicz-Tabaczek and Dzwonkowska [39]. The scale consists of 10 statements and the answers are rated on a 4 -point scale ( 1 - strongly agree to 4 - strongly disagree). Cronbach's $\alpha$ for this scale was 0.71 .

\section{Statistical analyses}

The first step of the Exploratory Factor Analysis (EFA) was performed in IBM SPSS Statistics for Windows, Version 22.0, to verify whether the items could be assigned to the theoretically assumed factors. The Principal Axis method with Promax rotation where factors can be correlated was used. An alternative analysis involving Principal Component Analysis (PCA) and Varimax rotation was con-

Table II. SEUS-48 Exploratory Factor Analysis, $N=587$

\begin{tabular}{|l|c|c|c|}
\hline Factor & Variance & $\begin{array}{c}\text { Total cumulated } \\
\text { variance, \% }\end{array}$ & $\begin{array}{c}\text { Number } \\
\text { of items }\end{array}$ \\
\hline 1 & 19.012 & 39.61 & 16 \\
\hline 2 & 2.497 & 44.81 & 8 \\
\hline 3 & 1.547 & 48.03 & 10 \\
\hline 4 & 1.433 & 51.02 & 7 \\
\hline 5 & 1.144 & 53.40 & 2 \\
\hline 6 & 1.059 & 55.61 & 2 \\
\hline 7 & 0.949 & 57.59 & 3 \\
\hline
\end{tabular}

ducted in STATISTICA v.10. The Kaiser criterion (eigenvalue greater than one) was used to determine the number of the identified factors [40]. The percent of explained variance was determined for different factor solutions. Reliability was measured with Cronbach's $\alpha$ at every step. The correlations between the variables were calculated with the use of Pearson's and Spearman's correlation coefficients.

The proposed theoretical model was verified in the Confirmatory Factor Analysis (CFA). The Maximum Likelihood method in AMOS v.21 was used. According to Schermelleh-Engel, Moosbrugger and Müller [41], the following goodnessof-fit parameters should be met: $\chi^{2}$ and $p>0.05$, $\chi^{2} / d f \leq 2$, GFI $\geq 0.95$, AGFI $\geq 0.90$, RMSEA $\leq 0.05$ and $\mathrm{CFI} \geq 0.97$.

\section{- RESULTS}

\section{SEUS construct validity}

The factor structure of the SEUS-48 (Study 1, $N=587$ ) was verified in EFA with Principal Axis Factoring and Promax rotation. Seven factors were modelled so the imposed number of factors was analysed first. The analysis revealed that only six out of the seven factors met the Kaiser's rule requirements. Table II presents the outcome of the EFA. Unfortunately, the presented solution does not coincide with the assumed structure, and the statements did not fit the theoretical distribution within the scale. It should be emphasised that the factor loadings for some items were below 0.4, which constituted the basis for their potential elimination [42]. Cronbach's $\alpha$ for 48 items was 0.964 , with mean correlation between the items at 0.38 .

The results of Study $2(N=351)$ were processed by CFA to determine whether the seven-factor solution of the SEUS- 48 was confirmed by the data. Unfortunately, the modelled parameters did not conform to the accepted values, which resulted in a poor goodness-of-fit: $\chi^{2}=2826.28, d f=1059$, $p<0.001, \chi^{2} / d f=2.669, \mathrm{GFI}=0.738$, AGFI $=0.709$, RMSEA $=0.069$ (0.066-0.072), CFI $=0.752$. Cronbach's $\alpha$ was 0.952 , and the mean correlation between the items was 0.30 .

In view of the above, the number of factors was reduced to four (in EFA, the four-factor solution was optimal, and the seven-factor model had poor goodness-of-fit) and the number of scale items was decreased. The number of factors was reduced in Principal Component Analysis (PCA) 
Table III. Items phrasing, factor loadings and reliability indicators of SEUS-14, $N=538$

\begin{tabular}{|l|l|c|c|}
\hline & To what extent do you agree or disagree with the following statements* & $\begin{array}{c}\text { Factor } \\
\text { loadings }\end{array}$ & $\begin{array}{c}\text { Item-total } \\
\text { correlation }\end{array}$ \\
\hline 1. & I cannot fall asleep because of SNS usage. & 0.73 & 0.68 \\
\hline 2. & Experienced failures (quarrels with friends, bad grades etc.) creates a desire to use SNS. & 0.73 & 0.68 \\
\hline 3. & My friends complain that I spend too much time on using SNS. & 0.74 & 0.69 \\
\hline 4. & When I feel that I lack energy, then I use SNS - it allows me to “recharge my batteries". & 0.74 & 0.70 \\
\hline 5. & In order to use SNS I sleep less than before. & 0.79 & 0.75 \\
\hline 6. & It is difficult to limit the time I spend on SNS. & 0.74 & 0.70 \\
\hline 7. & Being on SNS is my favourite hobby. & 0.74 & 0.69 \\
\hline 8. & $\begin{array}{l}\text { I can see that through the use of SNS my relationship with my parents (guardians) } \\
\text { has significantly deteriorated. }\end{array}$ & 0.79 & 0.75 \\
\hline 9. & I have abandon my other favourite activities in order to have more time to enjoy SNS. & 0.82 & 0.78 \\
\hline 10. & When I feel bad, then I go on SNS to improve my mood. & 0.73 & 0.68 \\
\hline 11. & After a session on SNS, I feel that I have to return there as soon as possible. & 0.75 & 0.71 \\
\hline 12. & $\begin{array}{l}\text { Because of the functioning on SNS I get into more arguments with friends from } \\
\text { the "real world". }\end{array}$ & 0.77 & 0.72 \\
\hline 13. & When I have nothing to do, I immediately imagine what I would do on SNS. & 0.77 & 0.72 \\
\hline 14. & $\begin{array}{l}\text { It happens to me to deceive my loved ones (family, friends) about how much daily } \\
\text { time I spend on SNS. }\end{array}$ & 0.80 & 0.76 \\
\hline
\end{tabular}

"The answers were given based on the Likert scale where 1 corresponds to strongly disagree and 5-strongly agree.

with Varimax rotation, and four factors were selected. An item was eliminated from the scale when factor loading was low (below 0.4) and when the item's content was incompatible with the remaining items of a given factor. The above procedure supported the elimination of 18 items, and the remaining items were incorporated into the SEUS-30 where four factors explained 55.03\% of the variance. The first factor, "Negative consequences", was composed of six items; the second factor, "Time", had seven items; the third factor, "Mood modification", consisted of six items and "Preoccupation", the last factor, had 12 items.

The structure of the SEUS-30 was verified in the third study involving 1054 participants, but the sample (Sample 3 ) was randomly divided into two samples. Sample $3 a(N=516)$ was used in CFA and Sample $3 \mathrm{~b}(N=538)$ in PCA. The CFA was performed to determine whether the four factor solution was the final version of the scale. Unfortunately, the values of the model parameters in the CFA were not satisfactory: $\chi^{2}=1601.22$, $d f=399, p<0.001, \chi^{2} / d f=4.013, \mathrm{GFI}=0.799$, AGFI $=0.765$, RMSEA $=0.076(0.073-0.080)$, $\mathrm{CFI}=0.850$. Therefore the four-factor solution was abandoned, a single factor was identified in PCA and the results were used to reduce the number of statements. The results were consistent with the previous EFA findings which revealed that a single factor was largely responsible for the highest percentage of explained variance. It was assumed that the item could be incorporated into the scale if its factor loading reached 0.7. As a result, 16 items were eliminated and only 14 items were incorporated into the scale. The SEUS-14 and factor loadings for 14 items are presented in Table III. Cronbach's $\alpha$ for the scale was 0.94 and the mean correlation between the items was 0.55 .

\section{SEUS criterion validity}

Concurrent validity was determined with the use of the BFAS, and the results were correlated with the overall SEUS-48 score (data from Sample 1). Facebook addiction and problematic use of social media were bound by a strong correlation (SEUS-48, $r=0.80, p<0.001$ ). The obtained result is consistent with previous assumptions and confirms the high concurrent SEUS validity. A simulation was carried out regarding the potential functioning of the shorter version of the scale and its relationship with BFAS. Of the 48 statements making up SEUS-48, those that were included in the final version of the SEUS-14 scale were extracted and used to perform additional analysis of correlation with the BFAS scale. The result showed that 
Table IV. Mean scores and correlations between SEUS14 and variables included in the validation process

\begin{tabular}{|c|c|c|}
\hline \multirow[t]{2}{*}{ Variables } & \multicolumn{2}{|c|}{ Sample $3(N=1054)$} \\
\hline & $M \pm S D$ & SEUS-14 \\
\hline \multicolumn{3}{|l|}{ SEUS-14 } \\
\hline $\begin{array}{l}\text { Excessive Use } \\
\text { of SNS }\end{array}$ & $24.59 \pm 10.83$ & - \\
\hline \multicolumn{3}{|l|}{ HEXACO-PI-R } \\
\hline Honesty-Humility & $3.08 \pm 0.65$ & $-0.11^{\star \star *}$ \\
\hline Emotionality & $3.07 \pm 0.61$ & 0.05 \\
\hline Extraversion & $3.23 \pm 0.54$ & $-0.07^{\star}$ \\
\hline Agreeableness & $3.09 \pm 0.50$ & $-0.09^{* *}$ \\
\hline Conscientiousness & $3.26 \pm 0.52$ & $-0.20^{\star * *}$ \\
\hline $\begin{array}{l}\text { Openness to } \\
\text { Experience }\end{array}$ & $3.21 \pm 0.56$ & $-0.16^{\star * *}$ \\
\hline \multicolumn{3}{|l|}{ BIS/BAS Scales } \\
\hline BIS & $16.84 \pm 3.44$ & -0.04 \\
\hline BAS & $28.68 \pm 4.31$ & $-0.27^{\star \star \star}$ \\
\hline \multicolumn{3}{|l|}{ NPI } \\
\hline NPI total score & $104.09 \pm 22.29$ & 0.06 \\
\hline $\begin{array}{l}\text { Demands for } \\
\text { admiration }\end{array}$ & $32.82 \pm 8.55$ & $0.13^{* * *}$ \\
\hline Vanity & $14.45 \pm 4.26$ & $0.10^{\star *}$ \\
\hline Self-sufficiency & $24.32 \pm 4.53$ & $-0.16^{\star * *}$ \\
\hline Leadership & $32.50 \pm 8.61$ & 0.05 \\
\hline \multicolumn{3}{|l|}{ SES } \\
\hline Self-esteem & $27.00 \pm 4.27$ & $-0.16^{\star \star \star}$ \\
\hline \multicolumn{3}{|c|}{ SUQ (categorical variables on the ordinal scale) } \\
\hline $\begin{array}{l}\text { Daily time spending } \\
\text { on SNS }\end{array}$ & - & $0.30^{* * *}$ \\
\hline $\begin{array}{l}\text { Frequency of photo } \\
\text { adding }\end{array}$ & - & $0.22^{* \star *}$ \\
\hline $\begin{array}{l}\text { Frequency of profile } \\
\text { photo changing }\end{array}$ & - & $0.28^{* \star *}$ \\
\hline
\end{tabular}

Spearman correlation coefficients were used for express relation between SEUS and SUQ.

$M-$ mean; $S D$ - standard deviation; ${ }^{*} p<0.05,{ }^{* *} p<0.01$, ${ }^{* * *} p<0.001$

the short version of the tool still highly correlates with BFAS $(r=0.77, p<0.001)$. This simulation was dictated by the use of the BFAS scale only in Sample 1 - the SEUS scale was reduced in subsequent stages, where no further use of the BFAS scale was planned.

Several variables were used in the analysis of convergent validity, and they were correlated with the SEUS-14 (Sample 3). The correlation coefficients are presented in Table IV. In general, the obtained results demonstrated the acceptable criterion validity of the new measure.

\section{- Discussion}

The main aim of the study was to develop a tool for measuring excessive use of social networking sites that would be targeted primarily at adolescents and would present satisfactory psychometric properties. Several procedures were deployed to create the final fourteen-question version of the Scale of Excessive Use of Social Networking Sites. The scale's reliability was very high as internal consistency measured with Cronbach's $\alpha$ exceeded 0.9 , and item-total correlation was greater than 0.65 for every item.

The scale's construct and criterion validity was verified in the validation process. The initial number of 48 items was validated in the EFA procedure which did not confirm the presence of the seven theoretically assumed factors. The CFA did not support positive verification of the hypothesis either. The collected data (from EFA and CFA) were used to abridge the tool to 30 items and four factors though this solution was not confirmed by new data. Therefore we decided to adopt a one-factor solution and shorten the scale while maintaining the items with the highest factor loadings. The resulting scale explained more than $55 \%$ of variance, which can be regarded as a satisfactory result in view of Merenda's [43] claim that total variance extracted should be greater than $50 \%$.

Criterion validity was analysed as concurrent and convergent validity. Concurrent validity was evaluated with the BFAS. As expected, the SEUS48 (the longer version) was highly correlated with the BFAS $(r=0.80)$. Therefore it can be concluded that the newly developed scale supported a correct assessment of the measured phenomenon however additional analyses should be carried out in subsequent studies using the short version SEUS-14 and the BFAS scale to re-verify their relationship.

Convergent validity was analysed by correlating the SEUS with several psychological variables related to the use of SNS. Based on the published research on internet addiction [26, 27] and problematic SNS usage $[3,4,13,44-46]$, we assumed that personality traits would be correlated with the results of the SEUS. With the exception of Emotionality, the remaining personality traits were significantly correlated with the SEUS-14 
though the observed correlations could be regarded as "low".

The strongest correlation was noted between the SEUS and Conscientiousness, and the correlation coefficient was negative. This indicates that the lower the conscientiousness score, the higher the SEUS-14 score, which suggests that Conscientiousness is inversely correlated with problematic/ excessive SNS use. Similar relationships were reported in other studies $[3,4,13,28,44,45]$.

Openness to experience was negatively correlated with the SEUS, which indicates that people who are more "down-to-earth" and prefer to focus on what is known have a higher tendency to engage in problematic SNS usage. This outcome is consistent with the findings of other authors $[13,28$, $44]$ though in some studies $[3,4]$ this trait was not a significant predictor of SNS addiction.

The correlation between Extraversion and the SEUS was confirmed. Based on published data $[3,4,45]$, we assumed that the correlation would be positive, but the collected data revealed that more introverted adolescents scored higher in the SEUS-14. The correlation between Extraversion and the SEUS could be difficult to interpret due to ambiguous findings. Our findings contradict the results of Polish studies [13, 44] where Extraversion was not significantly correlated with Facebook addiction. Our results could be explained with the social compensation hypothesis which states that introverted and socially anxious adolescents are more likely to engage socially online than offline [47]. Our results suggest that more introverted students who use SNS to compensate for their lack of social skills are more likely to use SNS in an addictive manner. They could be inclined to use SNS more often if they experience positive feedback, but this scenario cannot be verified in a cross-sectional study.

The last two personality traits, Agreeableness and Honesty-Humility, were also negatively correlated with excessive use of SNS, which is consistent with previous findings $[44,45]$. Adolescents who are less agreeable and less honest scored higher in the SEUS. Direct references to Honesty-Humility are scarce in the literature because the six-factor personality model is less widely used in research on behavioural addictions than the Big Five solution. To the best of the authors' knowledge, Facebook addiction and HonestyHumility have been addressed by only one confer- ence report [48] to date. The reported correlation was negative, which corroborates our results.

Our results indicate that adolescents who have a higher demand for admiration are more likely to use SNS excessively. Vanity was bound by a similar correlation with SEUS-14 scores, which is consistent with previous research showing the mutual positive relationship between narcissism and SNS addiction [6]. SNS are conducive to the manifestation of narcissistic behaviour, and they are highly attractive for people who need to be admired or to externalise their vanity, which is manifested by self-preoccupation on the NARPI scale [37]. Self-sufficiency, one of the four aspects of narcissism, was negatively correlated with excessive SNS use, which suggests that adolescents who see themselves as less competent and independent use SNS excessively.

The SEUS-14 was also negatively correlated with the BAS. This is a surprising result which runs counter to the recently reported correlation between the BAS and internet addiction. However, a negative correlation was reported by Andreassen et al. [3], where Fun seeking, one of the BAS subscales, was a significant predictor of Facebook addiction. In our study, the correlation between the BIS and the SEUS was not significant. Similar findings were reported in other studies on Facebook [3] or internet addiction [24]. According to Nam et al. [25], the observed inconsistencies could suggest that BIS/BAS in itself is a not a sufficient predictor of addictive behaviour. Therefore, SNS addiction and the BIS are probably bound by a more complex relationship that could be difficult to identify in a simple correlation analysis.

As expected, self-esteem was negatively correlated with the SEUS. Adolescents with lower self-esteem are more likely to use SNS excessively. Our results are consistent with the published findings $[6,11,23,28]$. Based on the social compensation hypothesis, it could be assumed that positive feedback from SNS can enhance self-esteem, in particular in individuals whose sense of self-worth is derived from external rather than internal factors.

Positive correlations were noted between daily time spent on SNS and the SEUS-14, which is consistent with expectations. Similar findings were presented by van den Eijnden et al. [11] where SNS addiction was significantly related to the frequency of daily SNS usage. This seemingly intuitive re- 
sult does not follow from the criteria of potential SNS addiction because there is no clearly defined time range to suggest problematic or excessive SNS use. The frequency of posting and changing profile photos was also bound by a positive correlation with SEUS results. In SNS like Facebook, these activities elicit comments or "likes" from other users. As a result, the profile owner may be encouraged to post more photos or change them more frequently, which can lead to excessive SNS use. However, the above hypothesis could not be verified by our cross-sectional study.

It should be noted that the SEUS was developed and validated on a nationwide sample of young people. The respondent samples in each of the three studies were gender balanced. The proposed tool does not have pre-set standards, and it can be used as a screening tool where a higher score indicates a higher severity of the problem. Due to the lack of unambiguous and universally recognised criteria for evaluating SNS addiction, the SEUS score cannot be the sole basis for classifying respondents as potentially addicted and every diagnosis should be preceded by an appropriate interview.

\section{Limitations}

The present study is not free from limitations. The initial criteria (based on DSM-IV and research into internet addiction) for developing the SEUS questions were one of the research limitations. The diagnostic criteria for the Internet Gaming Disorder [49], which are commonly used in research on behavioural addiction, had not been widely known at the time the SEUS was developed. The correlation coefficients were generally low, and further analyses, like SEM or Path Analysis, are required to account for the direct correlations between variables. The use of the HEXACO Personal Inventory was yet another limitation because the value of the reliability coefficient of selected factors in the analysed sample was below 0.7. Despite the above, this measure added value to our study because it is not widely used for research in the field of behavioural addiction. The study lacked a procedure for comparing SEUS-14 re- sults with expert opinions on SNS addiction severity (multilateral assessment). The applied research tools were self-reported, and they could be burdened with error resulting from the respondents' attitude to the test, which is an important consideration in studies of adolescents. The study did not include a direct comparison of results obtained through the SEUS scale and another tool for assessing the problem of using SNS as this should be included in subsequent studies. In addition, checking whether SEUS14 and e.g. BFAS correlate with other variables (e.g. personality, self-esteem) in a similar range would give a more precise answer to whether these two tools measure similar constructs. As a result it would be possible to assess which of the indicated tools is better. The instructions for the SEUS do not specify a reference period for reporting online activity, which could influence the results, especially that a period of one year seems to be excessive in a study of teens. It should also be noted that at the time the SEUS was developed, smartphones were less widely used by teenagers with internet and SNS access. At present, many people, including adolescents, access SNS through mobile devices, which could intensify SNS addiction symptoms and prevent accurate determination of the time spent on social media. It should be taken into account that present SNS, compared to 2013 and 2014, have more diverse characteristics. They are based more on the visual message and graphic processing activities, hence the question is whether the proposed tool will be able to capture the problematic use of specific SNS like Tik Tok. It is therefore advisable to examine whether certain activities can be more addictive on SNS than others in subsequent studies.

\section{CONCLUSIONS}

The studies conducted on a sample of Polish adolescents revealed good psychometric properties for SEUS-14. The measure can be used as a screening tool for scientific purposes though further research is required to determine its applicability in large-scale studies. 


\section{Acknowledgements/Podziękowania}

We would like to thank Professor Paweł Izdebski and Paulina Andryszak, PhD for their help in conducting the research./Dziękujemy prof. Pawłowi Izdebskiemu i dr Paulinie Andryszak za pomoc w przeprowadzeniu badań.

\section{Conflict of interest/Konflikt interesów}

None declared./Nie występuje.

\section{Financial support/Finansowanie}

Gambling Problem Solving Fund, contracts no 73/HE/13; 3/HEK/2014./Fundusz Rozwiązywania Problemów Hazardowych, nr umów 73/HE/13, 3/HEK/2014.

\section{Ethics/Etyka}

The work described in this article has been carried out in accordance with the Code of Ethics of the World Medical Association (Declaration of Helsinki) on medical research involving human subjects, Uniform Requirements for manuscripts submitted to biomedical journals and the ethical principles defined in the Farmington Consensus of 1997.

Treści przedstawione w pracy są zgodne z zasadami Deklaracji Helsińskiej odnoszącymi się do badań z udziałem ludzi, ujednoliconymi wymaganiami dla czasopism biomedycznych oraz z zasadami etycznymi określonymi w Porozumieniu z Farmington w 1997 roku.

\section{References/Piśmiennictwo}

1. Clement J. Facebook: number of daily active users worldwide 2011-2020. https://www. statista.com/statistics/346167/facebook-global-dau/ (Accessed: 11.11.2020).

2. Griffiths MD. A 'components' model of addiction within a biopsychosocial framework. J Subst Use 2005; 10: 191-7.

3. Andreassen CS, Torsheim T, Brunborg GS, Pallesen S. Development of a Facebook addiction scale. Psychol Rep 2012; 110(2): 501-17.

4. Wilson K, Fornasier S, White KM. Psychological predictors of young adults' use of social networking sites. Cyberpsychol Behav Soc Netw 2010; 13: 173-7.

5. Griffiths MD. Facebook Addiction: Concerns, criticism, and recommendations - a response to Andreassen and Colleagues. Psychol Rep 2012; 110(2): 518-20.

6. Andreassen CS, Pallesen S, Griffiths MD. The relationship between addictive use of social media, narcissism, and self-esteem: Findings from a large national survey. Addict Behav 2017; 64: 287-93.

7. Elphinston RA, Noller P. Time to face it! Facebook intrusion and the implications for romantic jealousy and relationship satisfaction. Cyberpsychol Behav Soc Netw 2011; 14(11): 631-5.

8. Young KS. Caught in the Net: How to Recognize the Signs of Internet Addiction and a Winning Strategy for Recovery. New York: John Wiley \& Sons; 1998.

9. Hong F, Huang D, Lin H, Chiu S. Analysis of the psychological traits, Facebook usage, and Facebook addiction model of Taiwanese university students. Telematics and Informatics 2014; 31(4): 597-606.

10. Caci B, Cardaci M, Scrima F, Tabacchi ME. The dimensions of Facebook addiction as measured by Facebook Addiction Italian Questionnaire and their relationships with individual differences. Cyberpsychol Behav Soc Netw 2017; 20(4): 251-8.

11. van den Eijnden RJJM, Lemmens J, Valkenburg P. The Social Media Disorder Scale. Comput Human Behav 2016; 61: 478-87.

12. Mamun MA, Griffiths MD. The association between Facebook addiction and depression: A pilot survey study among Bangladeshi students. Psychiatry Res 2019; 271: 628-33.

13. Błachnio A, Przepiórka A. Personality and positive orientation in Internet and Facebook addiction. An empirical report from Poland. Comput Human Behav 2016; 59: 230-6. 
14. Błachnio A, Przepiórka A, Pantic I. Association between Facebook addiction, self-esteem and life satisfaction: a cross-sectional study. Comput Human Behav 2016; 55: 701-5.

15. Wolniczak I, Cáceres-DelAguila JA, Palma-Ardiles G, Arroyo KJ, Solís-Visscher R, Paredes-Yauri S, et al. Association between Facebook dependence and poor sleep quality: a study in a sample of undergraduate students in Peru. PLoS One 2013; 8(3): e59087.

16. Tang JH, Chen MC, Yang CY, Chung TY, Lee YA. Personality traits, interpersonal relationships, online social support, and Facebook addiction. Telematics and Informatics 2016; 33(1): 102-8.

17. Andreassen CS. Online Social Network Site Addiction: a comprehensive review. Curr Addict Rep 2015; 2: 175-84.

18. World Health Organization. The ICD-10 classification of mental and behavioural disorders: Clinical descriptions and diagnostic guidelines. World Health Organization; [1992.

19. American Psychiatric Association. Diagnostic and statistical manual of mental disorders: DSM-IV. $4^{\text {th }}$ ed. Washington, DC; 2000.

20. Young KS. Internet addiction: The emergence of a new clinical disorder. Cyberpsychol Behav 1998; 1: 237-44.

21. Corr PJ. Reinforcement Sensitivity Theory and personality. Neurosci Biobehav Rev 2004; 28: 317-32.

22. Pickering A, Gray JA. Dopamine, appetitive reinforcement, and the neuropsychology of human learning: an individual differences approach. In: Eliasz A, Angleitner A (eds.). Advances in research on temperament. Lengerich, Germany: PABST Science Publishers; 2001, p. 113-49.

23. Meerkerk GJ, van den Eijnden RJJM, Franken IHA, Garretsen HFL. Is compulsive internet use related to sensitivity to reward and punishment, and impulsivity? Comput Human Behav 2010; 26(4): 729-35.

24. Park SM, Park YA, Lee HW, Jung HY, Lee JY, Choi JS. The effects of behavioral inhibition/approach system as predictors of Internet addiction in adolescents. Pers Individ Dif 2012; 54: 7-11.

25. Nam CR, Lee DH, Lee JY, Choi AR, Chung SJ, Kim DJ, et al. The role of resilience in Internet addiction among adolescents between sexes: a moderated mediation model. J Clin Med 2018; 7(8): 222.

26. Cao F, Su L. Internet addiction among Chinese adolescents: prevalence and psychological features. Child Care Health Dev 2006; 33(3): 275-81.

27. Huang X, Zhang H, Li M, Wang J, Zhang Y, Tao R. Mental health, personality, and parental rearing styles of adolescents with Internet Addiction Disorder. Cyberpsychol Behav 2010; 13(4): 401-6.

28. Atroszko PA, Balcerowska JM, Bereznowski P, Biernatowska A, Pallesen S, Andreassen CS. Facebook addiction among Polish undergraduate students: validity of measurement and relationship with personality and well-being. Comput Human Behav 2018; 85: 329-38.

29. Brailovskaia J, Schillack H, Margraf J. Facebook Addiction Disorder in Germany. $C y$ berpsychol Behav Soc Netw 2018; 21(7): 450-6.

30. Mehdizadeh S. Self presentation 2.0: narcissism and self-esteem on Facebook. Cyberpsychol Behav Soc Netw 2010; 13: 357-64.

31. Ryan T, Xenos S. Who uses Facebook? An investigation into the relationship between the Big Five, shyness, narcissism, loneliness, and Facebook usage. Comput Human Behav 2011; 27(5): 1658-64.

32. Ashton MC, Lee K. The HEXACO-60: a short measure of the major dimensions of personality. J Pers Assess 2009; 91: 340-5.

33. Carver CS, White TL. Behavioral inhibition, behavioral activation, and affective responses to impending reward and punishment: the BIS/BAS scales. J Pers Soc Psychol 1994; 67: 319-33.

34. Müller JM, Wytykowska A. Psychometric properties and validation of a Polish adaptation of Carver and White's BIS/BAS scales. Pers Individ Dif 2005; 39: 795-805.

35. Berantowicz D. Temperament wedtug J.A. Graya a wynik sportowy: Badanie quasi-eksperymentalne (niepublikowana praca doktorska). Bydgoszcz: Uniwersytet Kazimierza Wielkiego; 2016. 
36. Raskin R, Hall CS. The Narcissistic Personality Inventory. Psychol Rep 1979; 45: 159-62.

37. Bazińska R, Drat-Ruszczak K. Structure of narcissism in the Polish adaptation of the Narcissistic Personality Inventory. Czasopismo Psychologiczne 2000; 6: 171-88.

38. Rosenberg M. Society and the adolescent self-image. Princeton, NJ: Princeton University Press; 1965.

39. Łaguna M, Lachowicz-Tabaczek K, Dzwonkowska I. Skala Samooceny SES Morrisa Rosenberga - polska adaptacja metody. Psychologia Spoleczna 2007, 2: 164-76.

40. Kaiser HF. The application of electronic computers to factor analysis. Educational and Psychological Measurement 1960, 20: 141-51.

41. Schermelleh-Engel K, Moosbrugger H, Müller H. Evaluating the fit of structural equation models: tests of significance and descriptive goodness-of-fit measures. Methods of psychological research online 2003; 8: 23-74.

42. Stevens JP. Applied multivariate statistics for the social sciences, $2^{\text {nd }}$ ed. Hillsdale, NJ: Lawrence Earlbaum Associates; 1992.

43. Merenda PF. A guide to the proper use of factor analysis in the conduct and reporting of research: Pitfalls. Meas Eval Couns Dev 1997; 30(3): 156-64.

44. Błachnio A, Przepiórka A, Senol-Durak E, Durak M, Sherstyuk L. The role of personality traits in Facebook and Internet addictions: a study on Polish, Turkish, and Ukrainian samples. Comput Human Behav 2017; 68: 269-75.

45. De Cock R, Vangeel J, Klein A, Minotte P, Rosas O, Meerkerk GJ. Compulsive use of social networking sites in Belgium: prevalence, profile, and the role of attitude toward work and school. Cyberpsychol Behav Soc Netw 2014; 17: 166-71.

46. Wang CW, Ho RT, Chan CL, Tse S. Exploring personality characteristics of Chinese adolescents with internet-related addictive behaviors: Trait differences for gaming addiction and social networking addiction. Addict Behav 2015; 42: 32-5.

47. McKenna KYA, Bargh JA. Plan 9 from Cyberspace: the Implications of the Internet for Personality and Social Psychology. Pers Soc Psychol Rev 2000; 4(1): 57-75.

48. Goljović N. Personality traits, Self-Concept and Life Satisfaction in the context of Facebook use. In: Proceedings of the XXIII Scientific Conference - Empirical Studies in Psychology, March 24-26, 2017 Faculty of Philosophy, University of Belgrade. Belgrade: Institute of Psychology, Laboratory for Experimental Psychology, Faculty of Philosophy, University of Belgrade; 2017, p. 96-102.

49. American Psychiatric Association. Diagnostic and Statistical Manual of Mental Disorders: DSM-5. $5^{\text {th }}$ ed. Arlington, VA; 2013. 
